\title{
Abundance and Diversity of Bryofauna in Coffee and Tea Vegetations
}

\author{
Rully Rahadian $^{a}$, Lilih Khotimperwati ${ }^{b}$ and Karyadi Baskoro ${ }^{c}$ \\ a,b,c Faculty of Sciences and Mathematics, Diponegoro University, Semarang, Indonesia \\ E-mail : 'arully.rahadian@live.undip.ac.id, blieh_lilih@yahoo.com, ${ }^{\mathrm{c}}$ baskoro@yahoo.com
}

\begin{abstract}
Forest alteration into agroecosystem affect many organisms including bryofauna which their survivorship depend much on their host. Coffee and tea plantation are common agroecosystem in Indonesia. So far, the effect of habitat alteration on Bryofauna community have not been known yet. The objective of this study is to determine community structure attributes i.e., abundance, diversity and composition of bryofauna living in coffee and tea vegetation. The study was located in Ungaran Mountain, District of Semarang Indonesia. Bryofauna were extracted from moss using Tullgren funnel method and were identified until possible taxa. Bryofauna sampling was conducted both in coffee and tea vegetation. Bryofauna were extracted from the moss using Tullgren funnel method. The result shows that Acari was the most abundant both in coffee and tea area. Generally, bryofauna was more abundant in the coffee vegetation than in the tea vegetation. The diversity of bryofauna was not affected neither by altitude nor vegetation. However, the diversity of bryofauna seems affected more by their host, bryophyte.
\end{abstract}

Keywords: Bryofauna, Acari, coffee and tea vegetation.

\section{INTRODUCTION}

The diversity of invertebrate communities are well recognized to be rich in the soil, forest floor (Peck, J.E., and Moldenke, A.R., 2010), tree boles, and tree canopies (Lindo, Z., and Winchester, N.N. 2011). Bryophytes are well known has an association with invertebrate especially in providing habitat (Varga, J. 1992) and food for some species. Bryophyte mats are part of the structure of invertebrate that live on the forest floor or on the boles and branches of trees. In relation to patterns of diversity, there is a general pattern that diversity tend to be decline as altitude increases (Begon, et. al. 1990). Another ecology pattern which still the analogous of previous patterns that the decrease in species diversity is occurred as moving away from the tropics (Rosenzweig, 1995). Both these general patterns are believed to be responsible for the species diversity patterns in community structure and diversity (Begon, et. al. 1990). The pattern of species diversity along both latitudinal and altitudinal gradients have been studied using vascular plants and birds (Shepherd, 2009). However, along these gradients other taxonomic groups have different patterns of diversity, disputing the generality of both latitudinal and altitudinal gradient patterns (Hoover and Crossley, 2010).

Bryophyte and invertebrate communities are best candidate due to their habitat which can be found from the tropics to the polar regions and from sea level to above the tree line (Peck and Moldenke, 2010). In fact, bryophytes and their associated invertebrate communities have been relatively poorly studied especially in tropical region. Previous studies show that bryophytes in the tropics have a highest diversity in midaltitudinal peak (Andrew, et.al. 2003). The objectives of this study are to determine community structure attributes i.e., abundance, diversity and composition of bryofauna living in coffee and tea vegetation.

The following questions were addressed:

1. Did abundance of invertebrate mesofauna extracted from bryophytes vary at different agroecosystems i.e., coffee and tea vegetation?

2. Did diversity of invertebrate mesofauna extracted from bryophytes vary at different agroecosystems i.e., coffee and tea vegetation?

Was there any particular group of invertebrate taxon found in coffee and tea vegetation? 


\section{MATERIALS AND METHODS Study areas}

The experiment was conducted from March to August 2013 in Ungaran Mountain, Central Java, Indonesia. Bryofauna sample have been taken from two different altitudinal area which devided into 4 sampling stations as follow:
A. Station I: $1080 \mathrm{~m}$ a.s.l.
Coffee vegetation
Tea vegetation
B. Station II: $1528 \mathrm{~m}$ a.s.1.
Coffee vegetation
Tea vegetation

\section{Data collection and analysis}

Bryofauna which living on corticolous epiphytic bryophytes was sampled using quadrat method, $20 \times 30 \mathrm{~m}$. At each quadrat, sample was taken from five trees only if tree diameter was more than $20 \mathrm{~cm}$ and ten trees if the diameter range from 10 to $20 \mathrm{~cm}$. Sampling of bryofauna was applied on small plot, $10 \times 10 \mathrm{~cm}$, of tree trunk which located on $0.5-2 \mathrm{~m}$ from soil surface. At each station, five samples were taken. Bryoflora substrate which contain mesofauna were carried to Laboratory of Ecololgy and Biosystematics, Department of Biology, Diponegoro University for extracting mesofauna using an extractor based on the method by Tullgren (1918). The extraction used standard 25 W electric light bulbs.
Mesofauna were collected in small plastic bottles filled with $70 \%$ isopropanol. The extraction was terminated after 5 days. Mesofauna were identified up to the taxon level as lowest as possible according to Suhardjono, et. al. (2012), Gapud (2000), Jordana, et. al (1989). Briophytes within these samples were identified to species. Environmental parameter at each sampling station were recorded i.e. soil and air temperature, soil and air humidity, soil $\mathrm{pH}$, and light intensity. Mesofauna abundance, number of taxa, and Shannon-Wiener diversity indices were examined.

\section{RESULT AND DISCUSSION}

The abundance of bryofauna in the coffee vegetation was more abundant than in the tea vegetation. This pattern occurred consistently both in two different altitudinal sampling station. These occur because bryophite in coffee vegetation were richer than in tea vegetation. It found 35 species of bryophyte in the coffee vegetation compared to only 14 in the tea vegetation. Meanwhile, the structure of coffee vegetation seems provide a structural component to buffer more the moisture than the tea vegetation. Bates (1998) were demonstrate that significant relationships exist between the microhabitat conditions within the bryophyte cushions and the patterns of abundance of the invertebrate community.

Table 1. Densities of invertebrate (individu $100 \mathrm{gr}^{-1}$ ) living in bryophyte in two agroecosystems area of Mt. Ungaran.

\begin{tabular}{lccrr}
\hline \multirow{2}{*}{ Taxa } & \multicolumn{2}{c}{ B } & \multicolumn{2}{c}{ C } \\
& Cofee & Tea & Cofee & Tea \\
\hline Oribatida & 415 & 392 & 415 & 604 \\
\hline Isotomidae & 123 & 0 & 552 & 40 \\
\hline Mesostigmata & 69 & 58 & 211 & 95 \\
\hline Cicadelidae & 96 & 91 & 55 & 87 \\
\hline Entomobryidae & 14 & 25 & 96 & 135 \\
\hline Onychiuridae & 181 & 13 & 21 & 10 \\
\hline Ceratopogonidae & 85 & 39 & 67 & 25 \\
\hline Psycodidae & 41 & 21 & 62 & 34 \\
\hline Staphylinidae & 37 & 54 & 20 & 34 \\
\hline
\end{tabular}




\begin{tabular}{|c|c|c|c|c|}
\hline Formicidae & 12 & 56 & 4 & 55 \\
\hline Sciaridae & 35 & 16 & 6 & 61 \\
\hline Psocoptera & 34 & 9 & 63 & 10 \\
\hline Cecidomyiidae & 11 & 22 & 9 & 67 \\
\hline Prostigmata & 23 & 38 & 5 & 43 \\
\hline Araneida & 39 & 13 & 2 & 51 \\
\hline Carabidae & 13 & 12 & 4 & 31 \\
\hline Coccinellidae & 15 & 0 & 11 & 32 \\
\hline Nitidulidae & 34 & 13 & 0 & 5 \\
\hline Diplura & 0 & 0 & 0 & 44 \\
\hline Thysanoptera & 34 & 3 & 3 & 2 \\
\hline Chironomidae & 13 & 3 & 19 & 2 \\
\hline Hydroptilidae & 7 & 12 & 2 & 16 \\
\hline Miridae & 3 & 18 & 0 & 15 \\
\hline Phoridae & 5 & 6 & 7 & 15 \\
\hline larva diptera & 10 & 20 & 0 & 0 \\
\hline Larva Lepidoptera & 5 & 24 & 0 & 0 \\
\hline Symphypleona & 15 & 13 & 0 & 0 \\
\hline Larva insecta & 0 & 0 & 17 & 10 \\
\hline Flatidae & 5 & 0 & 0 & 16 \\
\hline Leiodidae & 0 & 0 & 11 & 9 \\
\hline Veliidae & 0 & 3 & 3 & 13 \\
\hline Scolytidae & 10 & 6 & 0 & 0 \\
\hline Polyxenida & 0 & 16 & 0 & 0 \\
\hline Drosophilidae & 5 & 9 & 0 & 0 \\
\hline Spechidae & 0 & 3 & 0 & 11 \\
\hline Pseudocorpionida & 7 & 7 & 0 & 0 \\
\hline Scelionidae & 0 & 3 & 0 & 9 \\
\hline Rhopalidae & 0 & 0 & 0 & 11 \\
\hline Isopoda & 8 & 0 & 1 & 0 \\
\hline Geophilomorpha & 3 & 0 & 0 & 5 \\
\hline Larva coleoptera & 8 & 0 & 0 & 0 \\
\hline Omaniidae & 0 & 0 & 0 & 8 \\
\hline Neuroptera & 0 & 7 & 0 & 0 \\
\hline Mordellidae & 5 & 0 & 0 & 0 \\
\hline Polidesmida & 0 & 0 & 5 & 0 \\
\hline Scolopendromorpha & 5 & 0 & 0 & 0 \\
\hline Symphila & 5 & 0 & 0 & 0 \\
\hline Aphididae & 0 & 0 & 3 & 0 \\
\hline Lathrididae & 0 & 3 & 0 & 0 \\
\hline Mymaridae & 0 & 3 & 0 & 0 \\
\hline
\end{tabular}




\begin{tabular}{lllll}
\hline Julida & 0 & 0 & 0 & 2 \\
\hline Neliidae & 0 & 0 & 1 & 0 \\
\hline
\end{tabular}

Table 2. Abundance, richness, evenness and diversity of bryofauna in coffee and tea vegetation of Mt. Ungaran.

\begin{tabular}{lcccc}
\hline \multirow{2}{*}{ Taxa } & \multicolumn{2}{c}{$\begin{array}{c}\text { B } \\
(1080 \mathrm{~m} \text { asl })\end{array}$} & \multicolumn{2}{c}{ C } \\
& Cofee & Tea & Cofee & Tea \\
\hline Number of individu & 1430 & 1029 & 1676 & 1607 \\
\hline Number of taxa & 36 & 34 & 28 & 34 \\
\hline Evenness, e & 0.75 & 0.73 & 0.63 & 0.73 \\
\hline Diversity, $\mathrm{H}^{\prime}$ & 2.68 & 2.57 & 2.09 & 2.58 \\
\hline
\end{tabular}

Since the tea were harvested specifically on their leaves in which directly affected on mesofauna living on it, harvesting of tea were probably acted as disturbance for bryofauna community. Even according to Glime (2013), disturbance were having little effect on the microarthopod fauna remaining in the bryophyte but other studies shows that disturbance that removes bryophytes typically results in a decrease in arthropods, at least temporarily.

The presence of bryofauna in the higher area (Station B) was more abundant compared to the lower one (Station A), regardless of its vegetation. It seems because of the higher area were more humid than in the lower one. For bryophytes, it is not the individual that forms the ecological unit, but rather the clonal or colonial life form Bate (1998). The life form is so constructed as to minimize evaporative loss while maximizing photosynthetic light capture. Glime (2013) stated that although diversity varied with altitude, there was no trend along the altitudinal gradient.

The diversity of bryofauna was not affected neither by altitude nor vegetation. However, the diversity of bryofauna seems affected more by their host, bryophyte. Glime (2013) suggested that bryophytes is important for the arthropod community. He suggested also that there were a positive correlation between bryophyte abundance and arthropod morphospecies in a study in Maine, USA.

Oribatida was consistently dominant either in each altitude or vegetation. We found that Oribatida were well adaptive to live on bryphite. According to Glime (2013), mites (Acari = Acarina) are common bryophyte inhabitants, especially the oribatids. Bryophytes provide a moist environment where movement up and down permits the mites to find the microclimate that best fulfills their needs and avoids damaging UV-B radiation. The bryophytes provide protective condition suitable for many species to use for egglaying. Other mites are fungal eaters that take advantage of the soil-bryophyte interface where conditions are good for fungal growth, and others feed on organisms living among the bryophytes. On the other hand, the mites often serve as food for other inhabitants of the bryophytes. 


\section{Cofee}

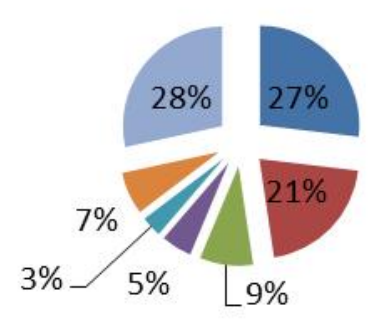

Tea

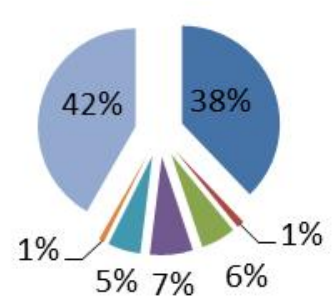

- Oribatida

Isotomidae

mesostigmata

- Cicadelidae

- Entomobryidae

Figure 1. Relative abundance $(\%)$ of bryofauna in coffee and tea vegetation of Mt. Ungaran

\section{CONCLUSION}

This study shows that the abundance of bryofauna at the coffee vegetation was higher than in the tea vegetation as well as the richness of bryophyte in each agroecosystems. There is no pattern of diversity of bryofauna in both agroecosystems. Oribatida was consistently dominant found in each agroecosystems and both in lower and higher area.

\section{ACKNOWLEDGMENT}

This study was fully supported by Hibah Bersaing Grant program (DIPA No: 0596/02304.2-16/13/2012) from the Ministry of Education and Culture, Indonesia. This paper was presented on the $3^{\text {rd }}$ International Seminar on New Paradigm and Innovation on Natural Sciences and Its Application (2013). The assistance of Lucia Puspita Anggraeni and Rina Eka Yuniarti in collecting and processing samples is appreciated.

\section{REFERENCES}

Andrew, N.R., L. Rodgerson \& M. Dunlop. 2003. Variation in invertebrate-bryophyte community structure at different spatial scales along altitudinal gradients. Journal of Biogreography, vol. 30, pp. 731-746.

Bates, J.W. 1998. Is 'life-form' a useful concept in byophite ecology? Oikos 82: 223-237.

Begon, M., J.L. Harper \& C.R. Towsend. 1990. Ecology: Individuals, populations and communities. Blackwell, Melbourne.

Gapud, V.P. 2000. Compilation of keys to the families of Philippines Insect. Department of Entomology of Agriculture University of the Philippines Los Banos College, Laguna.

Glime, J. M. 2013. Arthropods: Habitat Relations. Chapt. 7-1. In: Glime, J. M. Bryophyte Ecology. Volume 2. Bryological Interaction. 7-1-1 Last updated 14 August 2013 and available at <www.bryoecol.mtu.edu>.

Hoover, C.M \& D.A. Jr. Crossley. 2010. Leaf litter decomposition and microarthropod abundance along an altitudinal gradient, in "The significance and regulation of soil biodiversity." Pp. 287-292. Kluwer Academic Publisher, Dordrecht, The Netherlands.

Lindo, Z., \& N.N. Winchester. 1990. A comparison of microarthropod assemblages with emphasis on oribatid mites in canopy suspended soils and forest floors associated with ancient western red cedar trees. Pedobiologia, vol. 50, pp. 3141.

Peck, J.E., \& A.R. Moldenke. 2010. Invertebrate communities of subcanopy epiphyte mats subject to commercial moss harvest. $J$. Insect Conserv. Published online: 14 December 2010.

Rosenzweig, M.L. 1995. Species diversity in space and time. Cambridge University Press, Cambridge.

Shepherd, U.L. 2009. A comparison of species diversity and morphological diversity across the North American latitudinal 
gradient. Journal of Biogeography, 25, 19-29.

Suhardjono, Y.R., L. Deharveng, \& A. Bedos. 2012. Collembola (ekor pegas). Vegamedia, Bogor.

Jordana, R \& Y. Arbea. 1989. Clave de identification de Los Generos de Colembolos de Espana (Insecta: Collembola). Servico de Publicaciones de La Universidad de Navara. Pamplona.
Tullgren, A. 1918. Ein sehr einfacher Ausleseapparat für territole Tierfaunen. Z. angew. Ent. 4: 149-150, 1918. in Tiscia," A Tullgren-type extractor for sampling springtails populations from small volume soil cores in high sample size, Dombos, 2002.

Varga, J. 1992. Analysis of the fauna of protected moss species. Biol Cons., vol. 59, pp 171-173. 